\title{
Characterization of the genomic region containing the Shadow of Prion Protein (SPRN) gene in sheep
} Evelyne Lampo ${ }^{1}$, Mario Van Poucke1, Karine Hugot² ${ }^{2}$ Hélène Hayes ${ }^{3}$, Alex Van Zeveren ${ }^{1}$ and Luc J Peelman*1

Address: ${ }^{1}$ Department of Nutrition, Genetics and Ethology, Faculty of Veterinary Medicine, Ghent University, B-9820 Merelbeke, Belgium, ${ }^{2} \mathrm{CRB}$ GADIE, INRA, DGA, Laboratoire de Radiobiologie et d'Etude du Genome, INRA Jouy-en-Josas, F-78352 France ; 1CEA, DSV, DRR, Laboratoire de Radiobiologie et d'Etude du Genome, INRA Jouy-en-Josas, F-78352 France and ${ }^{3}$ UR 339 Unité de Génétique biochimique et Cytogénétique, INRA Jouy-en-Josas, F-78352 France

Email: Evelyne Lampo - Evelyne.Lampo@UGent.be; Mario Van Poucke - Mario.VanPoucke@UGent.be; Karine Hugot - Karine.Hugot@jouy.inra.fr; Hélène Hayes - Helene.Hayes@jouy.inra.fr; Alex Van Zeveren - Alex.VanZeveren@UGent.be; Luc J Peelman* - Luc.Peelman@UGent.be

* Corresponding author

Published: 30 May 2007

BMC Genomics 2007, 8:138 doi:10.1/86/147|-2164-8-138
Received: 29 January 2007

Accepted: 30 May 2007

This article is available from: http://www.biomedcentral.com/I47I-2/64/8/I38

(C) 2007 Lampo et al; licensee BioMed Central Ltd.

This is an Open Access article distributed under the terms of the Creative Commons Attribution License (http://creativecommons.org/licenses/by/2.0), which permits unrestricted use, distribution, and reproduction in any medium, provided the original work is properly cited.

\begin{abstract}
Background: TSEs are a group of fatal neurodegenerative diseases occurring in man and animals. They are caused by prions, alternatively folded forms of the endogenous prion protein, encoded by PRNP. Since differences in the sequence of PRNP can not explain all variation in TSE susceptibility, there is growing interest in other genes that might have an influence on this susceptibility. One of these genes is SPRN, a gene coding for a protein showing remarkable similarities with the prion protein. Until now, SPRN has not been described in sheep, a highly relevant species in prion matters.

Results: In order to characterize the genomic region containing SPRN in sheep, a BAC mini-contig was built, covering approximately 200,000 bp and containing the genes ECHSI, PAOX, MTGI, SPRN, LOC619207, CYP2EI and at least partially SYCEI. FISH mapping of the two most exterior BAC clones of the contig positioned this contig on Oari22q24. A fragment of 4,544 bp was also sequenced, covering the entire SPRN gene and 1206 bp of the promoter region. In addition, the transcription profile of SPRN in 21 tissues was determined by RT-PCR, showing high levels in cerebrum and cerebellum, and low levels in testis, lymph node, jejunum, ileum, colon and rectum.

Conclusion: Annotation of a mini-contig including SPRN suggests conserved linkage between Oari22q24 and Hsap 10q26. The ovine SPRN sequence, described for the first time, shows a high level of homology with the bovine, and to a lesser extent with the human SPRN sequence. In addition, transcription profiling in sheep reveals main expression of SPRN in brain tissue, as in rat, cow, man and mouse.
\end{abstract}

\section{Background}

TSEs are a group of fatal neurodegenerative diseases, caused by prions $\left(\mathrm{PrPSc}^{\mathrm{Sc}}\right)$. These infectious particles are alternatively folded forms of the endogenous protein PrPC, encoded by PRNP $[1,2]$. Conversion of PrPC into
$\mathrm{PrPSc}$ requires the presence of $\mathrm{PrPSc}$ and probably also of a not identified species-specific protein, 'protein $\mathrm{X}^{\prime}[3,4]$.

In sheep, TSE susceptibility is influenced by polymorphisms of the PRNP gene, with the alleles coding for 
alanine, arginine and arginine at positions 136, 154 and 171 of the prion protein associated with a high resistance to classical scrapie and BSE [5]. Nevertheless, this resistance is not absolute, since it has been shown that atypical scrapie can occur in sheep with the genotype ARR/ARR [6$11]$, sheep with this genotype can be artificially infected with BSE [12] and infectivity has been detected in the spleen of an ARR/ARR sheep, experimentally infected with BSE [13]. Moreover, the presumed resistance of ARR/ARR sheep might be due to a longer incubation period in these animals and subclinically infected sheep might transmit TSE infections unnoticed [14,15]. Therefore, there is growing interest in other genes and proteins which could have an influence on TSE susceptibility in sheep.

One of these genes is PRND, a PRNP homologue found near the PRNP gene and having structural and biochemical similarities with PRNP. However, no clear influence of PRND on TSE susceptibility has been found to date $[16,17]$. Also, a number of proteins with a high affinity for the prion protein, among which the $37-\mathrm{kDa} / 67-\mathrm{kDa}$ laminin receptor, have been discovered $[18,19]$ and could be important as 'protein $\mathrm{X}^{\prime}$ candidates. In addition, gene expression studies in the brain of scrapie-infected mice have identified a large number of genes, potentially involved in the pathogenesis of TSEs [20-22].

Based on comparative genomics, Premzl et al. [23] have discovered SPRN, a new candidate gene which codes for the Shadoo protein of 130-150 amino acids. This gene has already been described in man, mouse, rat, fish [23] and cow [24] and is predicted in chimpanzee (GenBank:XM 001146049). The Shadoo protein has also been identified in Sumatran orang-utan, rhesus macaque, white-tufted-ear marmoset, rabbit, guinea pig, dog, little brown bat, gray short-tailed opossum, chicken and western clawed frog [25]. An evolutionary model proposes that SPRN shares a common ancestor with PRNP [26], since it presents several important similarities with PRNP. First, the open reading frame of SPRN is located entirely in the last exon, with one preceding non-coding exon (one or two in PRNP) $[23,27]$. In addition, Shadoo is predicted to be extracellular and glycosylphosphatidylinositol-anchored. Moreover, the most remarkable structural feature of Shadoo is the presence of a hydrophobic sequence, composed of aliphatic amino acids and very similar to the hydrophobic sequence typically found in PrP and PrP-like proteins [23,28,29].

Apart from the structural similarities between SPRN and $P R N P$, the expression profile of SPRN also makes this gene an interesting candidate for further research. According to the results of RT-PCR and Northern blot analyses in cow [24], RT-PCR in rat [23], and cDNA, EST and SAGE map data in man and mouse [25], SPRN is mainly expressed in brain tissue, the most important target organ for prion infections. Since PrP knock-out mice [30] and cattle lacking the prion protein [31] show no major phenotypic changes, another gene, possibly SPRN, might take over the physiological function of the prion protein.

In this study, the genomic region containing SPRN in sheep was investigated using comparative mapping and sequencing and transcription profiling of the SPRN gene were performed.

\section{Results and discussion Construction and annotation of a BAC mini-contig containing SPRN}

The construction of a BAC contig containing SPRN was started by screening the INRA ovine BAC library with primers based on the genes PAOX and CYP2E1, with PAOX approximately 30,000 bp proximal from SPRN and CYP2E1 approximately 120,000 bp distal from SPRN, according to the human genome sequence. One BAC clone was found with the PAOX primers (OariBAC273H7) and two with the CYP2E1 primers (OariBAC265G4 and OariBAC567E3). Primers based on BESs of OariBAC273H7 and OariBAC265G4 did not permit to identify overlapping clones. Therefore, a new screening of the ovine BAC library was performed with the OariBAC273H7 UP primers, resulting in the identification of two new BAC clones (OariBAC182G04 and OariBAC161G10). Primers based on OariBAC161G10 BES (with one primer designed outside the repeat sequence, resulting in an amplicon of which $82 \mathrm{bp}$ are not part of any repetitive element) showed an overlap between the PAOX and the CYP2E1 subcontig. The total mini-contig thus consists of five BAC clones and is shown in Figure 1. Based on a comparison with the human genome sequence, the contig can be estimated to cover approximately 200,000 bp.

Both BESs and internal BAC sequences were used to annotate the contig. Sequencing of the BESs of the five clones resulted in ten sequences, of which four contain a high amount of repeat sequences (Genbank:EI184567, Genbank:EI184564, Genbank:EI184562 and Genbank:EI184563). Three BESs could be annotated, one (Genbank:EI184569) by comparison with the human genome sequence (Genbank:AL360181), and two (Genbank:EI184565 and Genbank:EI184561) by comparison with bovine genes, showing homology with the intron sequence of respectively ECHS1 (Genbank:DQ058603) and PAOX (Genbank:DQ058602). Three BESs revealed no relevant homology. Detailed information on the BESs is given in Table 1.

Comparison of internal BAC sequences with the human genome sequence revealed the presence of ECHS1, PAOX, 


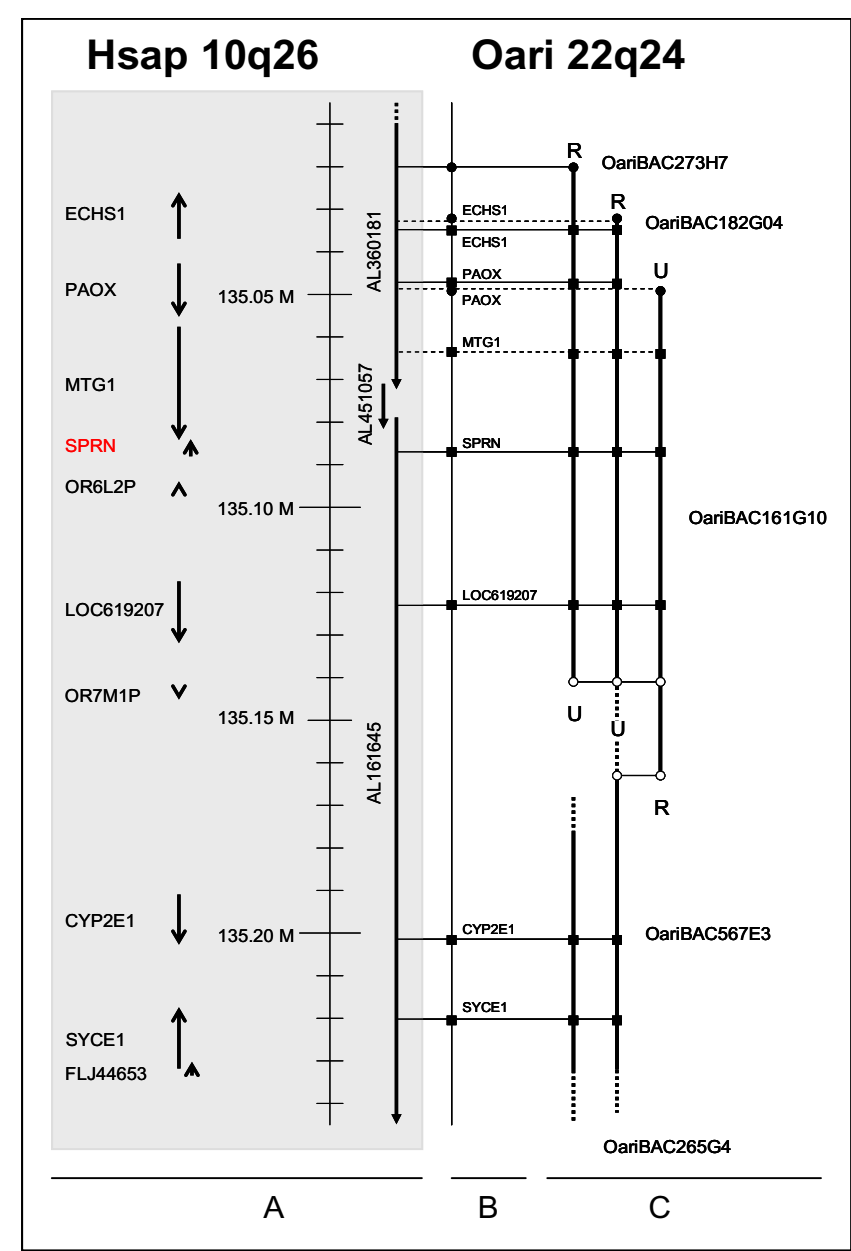

Figure I

Comparative mapping of the region containing SPRN in man and sheep. The position and orientation of the human genes and finished HTGs (used to assemble the human genome sequence) are represented in (A) by arrows. The annotated sequences from the BAC contig are shown in a plane map in part $B$. The sheep BAC contig is drawn in part C. White circles represent BESs used to design primers to construct the contig. Black circles represent annotated BESs. Black squares represent annotated internal BAC sequences. Full lines indicate sequence identity between the sheep sequence and the human sequence and dotted lines sequence identity between the sheep sequence and the bovine orthologue of the human gene on the indicated position. $U$ and $R$ represent respectively the BAC end obtained by the UP and the RP. $U$ and $R$ sides could not be determined for OariBAC265G4 and OariBAC567E3.

MTG1, SPRN, LOC619207, CYP2E1 and at least partial presence of SYCE1 in the contig. This is the first time that these genes have been identified in sheep. Due to lack of publicly available sequences in sheep or any related species, no suitable primers could be designed for the genes OR6L2P and OR7M1P, two genes also present in the human genome sequence corresponding to the sheep contig. Primers based on human sequences were tested for these genes, but no PCR product could be created on sheep DNA. All PCR products show a high level of homology with the human genome sequence, except that of MTG1, which shows homology only with the bovine sequence, probably because of the high intron content of the PCR product. Nucleotide identity and amino acid identity and positivity (amino acids are identical or share the same characteristics) of the amplicons with known sequences are shown in Table 2.

Order as well as orientation of the identified genes present in the sheep contig are identical to those of the corresponding region in man (Hsap10q26; human genome sequence), supporting conserved linkage between these species. In cattle, PAOX has an opposite orientation (Btau26q23; [24]). Remarkably, the block ECHS1, PAOX, MTG1 and SPRN seems highly conserved, as it is also found in man, mouse and even fugu [23]. The scavenger receptor close to SPRN in man and mouse, mentioned by Premzl et al. [23], is probably LOC619207 (as it codes for a scavenger receptor protein family member), and is therefore also present in the sheep contig.

\section{FISH mapping of the contig}

FISH mapping positioned clones OariBAC273H7 and OariBAC265G4 on chromosome Oari22q24 (Figures 2a and $2 \mathrm{~b}$ ). These results are in accordance with the heterologous chromosome painting data reported by Iannuzzi et al., showing correspondences between the distal part of human chromosome 10 and sheep chromosome 22 [32]. Moreover, the presence of OariBAC273H7 and OariBAC265G4, the most exterior BAC clones of the contig, on the same chromosome location, shows that no chromosome jumping has taken place during the construction of the contig. Localization of the contig maps the genes ECHS1, PAOX, MTG1, SPRN, LOC619207, CYP2E1 and SYCE1 to Oari22q24.

\section{Sequencing SPRN in sheep}

Sequencing of the SPRN gene was started with primers based on the bovine sequence NW_993476 (a contig containing SPRN partially). Next, primers based on the sheep SPRN sequence obtained during this work and primers based on the bovine sequence DQ058606 were used (Table 3). The overlapping amplicons resulted in a sequence of 4,544 bp, covering the entire SPRN gene and a stretch of $1206 \mathrm{bp}$ of the promoter region (Genbank:DQ870545). Exon 1 has a length of 108 bp, intron 1 a length of 735 bp and exon 2 a length of 2495 bp, of which 438 bp are coding sequence. All overlaps between the different amplicons (average overlap: $172 \mathrm{bp}$ ) were $100 \%$ identical. The intron/exon splice sites and the position of the coding sequence were determined by compar- 
Table I: Characteristics of the BESs.

\begin{tabular}{|c|c|c|c|}
\hline OariBAC clone & Accession number & Length sequence (bp) & $\begin{array}{c}\text { Annotation (repeats (class/family) or } \\
\text { nucleic acid identity with described sequences) }\end{array}$ \\
\hline 273H7-UP & ElI 84560 & 650 & No repeats, no homology found \\
\hline 273H7-RP & ElI 84569 & 723 & $\begin{array}{l}\text { Cow: NM_001076278: } 91 \% \\
\text { Man: AL360181: } 91 \%\end{array}$ \\
\hline 567E3-UP & EII 84567 & 752 & $\begin{array}{l}\text { 2I-I73: LIM4 (LINE/LI) } \\
\text { I60-752: BovB (LINE/RTE) }\end{array}$ \\
\hline 567E3-RP & ElI 84564 & 824 & 29-823: LIMA4A (LINE/LI) \\
\hline 265G4-UP & ElI 84562 & 743 & $\begin{array}{l}\text { I I4-257: MER34AI (LTR/ERVI) } \\
\text { 3 I8-426: LIMC3 (LINE/LI) } \\
\text { 498-688: LIMC3 (LINEI/LI) }\end{array}$ \\
\hline 265G4-RP & ElI 84566 & 454 & 246-278: TGGG(n) (simple repeat) \\
\hline I82G04-UP & ElI 84568 & $17 \mid$ & No repeats, no homology found \\
\hline I82G04-RP & ElI 84565 & 391 & Cow: DQ058603: 89\% \\
\hline I6IGI0-UP & ElI8456I & 267 & Cow: DQ058602: 89\% \\
\hline I6IGI0-RP & ElI 84563 & 306 & I-2।0: BovB (LINE/RTE) \\
\hline
\end{tabular}

Table 2: Amplicon characteristics of primers used for the annotation of the contig and the transcription profiling.

\begin{tabular}{|c|c|c|c|c|}
\hline $\begin{array}{l}\text { Gene symbol or } \\
\text { primer's name }\end{array}$ & $\begin{array}{l}\text { Forward primer }\left(5^{\prime}-3^{\prime}\right) \\
\text { Reverse primer }\left(5^{\prime}-3^{\prime}\right)\end{array}$ & $\begin{array}{l}\text { Ta }\left({ }^{\circ} \mathrm{C}\right) \\
\text { Length (bp) }\end{array}$ & $\begin{array}{l}\text { Accession } \\
\text { number } \\
\text { amplicons }\end{array}$ & $\begin{array}{l}\text { \% nucleic acid identity/amino acid identityl } \\
\text { amino acid positivity with described } \\
\text { sequences }\end{array}$ \\
\hline ECHSI & $\begin{array}{l}\text { GCAAAGAATGGGAAAGAACAGCA } \\
\text { GGCTCAAAAACCCGCCAGA }\end{array}$ & $\begin{array}{l}65 \\
646\end{array}$ & EF2I5853 & $\begin{array}{l}\text { OariEST (CD2888I8): 96/93/94 } \\
\text { BtauECHSI (DQ058603): 96/87/94 } \\
\text { HsapECHSI (NM_004092): 86/80/92 }\end{array}$ \\
\hline PAOX & $\begin{array}{l}\text { GCATCTGGACACCTTCTTTGA } \\
\text { GTCCTCCCACACCACCTG }\end{array}$ & $\begin{array}{l}65 \\
274\end{array}$ & EF2I5855 & $\begin{array}{l}\text { OariEST (DY499|83): 99/100/100 } \\
\text { BtauPAOX (DQ058602): 95/98/100 } \\
\text { HsapPAOX (NM_1529II): 90/88/94 }\end{array}$ \\
\hline MTGI & $\begin{array}{l}\text { CAGCTACCGCTATCACCGAGGA } \\
\text { GCGAGGACTTGCCCACGTT }\end{array}$ & $\begin{array}{l}60 \\
154\end{array}$ & EF2I5854 & BtauMTGI (DQ058604): 92/75/85 \\
\hline SPRN & $\begin{array}{l}\text { GCGAGGGTGCGTGTGAGG } \\
\text { CCTGAGGTCCACGCCCAGTA }\end{array}$ & $\begin{array}{l}68 \\
236\end{array}$ & - & $\begin{array}{l}\text { BtauSPRN (DQ058606): 95/92/93 } \\
\text { HsapSPRN (NM_00I0I2508): 79/76/80 }\end{array}$ \\
\hline LOC619207 & $\begin{array}{l}\text { GGCTGGTCAACGGCAGCA } \\
\text { GGCTCTGTCCCCACGCAGT }\end{array}$ & $\begin{array}{l}65 \\
220\end{array}$ & EF2I5856 & HsapLOC6I9207 (NT_0I7795): 88/73/84 \\
\hline CYP2EI & $\begin{array}{l}\text { AAGAAATTGACAGGGTGATTGG } \\
\text { AGGGAAGGAGGTCGATGAAT }\end{array}$ & $\begin{array}{l}60 \\
117\end{array}$ & $\mathrm{EF} 215857$ & $\begin{array}{l}\text { OariEST (EE790798): 98/100/100 } \\
\text { BtauCYP2EI (DQ058608): 98/97/100 } \\
\text { HsapCYP2EI (NM_000773): } 91 / 86 / 94\end{array}$ \\
\hline SYCEI & $\begin{array}{l}\text { GACAGCGGCAAGGAGCAGTT } \\
\text { GCTTCACATCCTCCAGCTTTGC }\end{array}$ & $\begin{array}{l}65 \\
149\end{array}$ & EF2I5858 & $\begin{array}{l}\text { BtauSYCEI(NM_00I038I49): 100/100/100 } \\
\text { HsapSYCEI (NT_0I7795): 90/90/90 }\end{array}$ \\
\hline OariBAC273H7 UP & $\begin{array}{l}\text { GGGACCATCCTGCTGTGACG } \\
\text { TCCACTGTCTGCGTCGTCCTC }\end{array}$ & $\begin{array}{l}65 \\
328\end{array}$ & ElI84560 & - \\
\hline OariBAC265G4 RP & $\begin{array}{l}\text { TGAGAGGTAAGAAGACCACCAAA } \\
\text { TCAACCGCAGAACTATGAACC }\end{array}$ & $\begin{array}{l}63 \\
287\end{array}$ & ElI84566 & - \\
\hline OariBACI6IGIO RP & $\begin{array}{l}\text { CAGCCTTGACGCACTCCTTT } \\
\text { TTTAGAACTGGGCCACACAGC }\end{array}$ & $\begin{array}{l}63 \\
200\end{array}$ & El 84563 & - \\
\hline АСТВ & $\begin{array}{l}\text { CGCAGACAGGATGCAGAAAGA } \\
\text { GCTGATCCACATCTGCTGGAA }\end{array}$ & $\begin{array}{l}60 \\
148\end{array}$ & DQ386889 & - \\
\hline UP & CGACGTTGTAAAACGACGGCCAG & $\begin{array}{l}55 \\
-\end{array}$ & - & - \\
\hline RP & $\begin{array}{l}\text { CACAGGAAACAGCTATGACCATG } \\
\text { ATTACG }\end{array}$ & $\begin{array}{l}55 \\
-\end{array}$ & - & - \\
\hline
\end{tabular}

For amplicons containing both exon and intron sequences (ECHSI, MTGI and SYCEI), sequence identity and positivity is shown for the exon parts of the amplicon. 


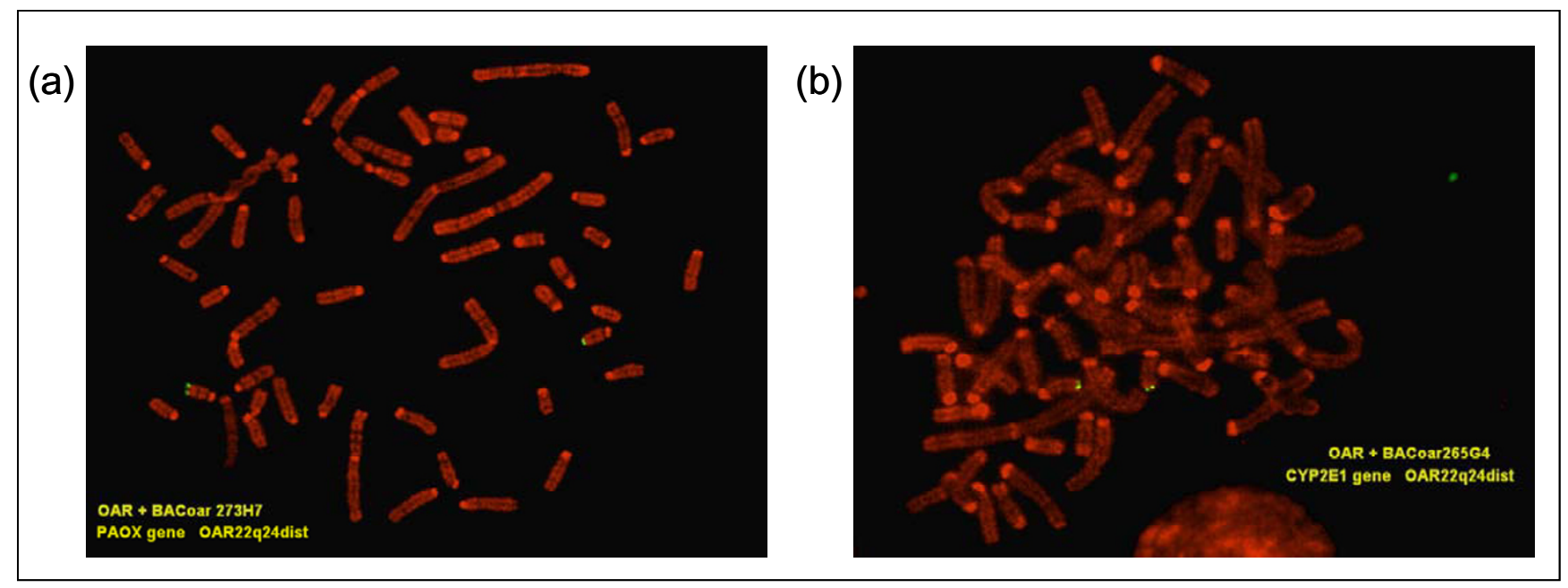

Figure 2

FISH localization of OariBAC273H7 and OariBAC265G4. (a) FISH map of OariBAC273H7 and (b) FISH map of OariBAC265G4.

ison with the bovine (Genbank:DQ058606) and human (Genbank:NW_001012508) SPRN sequences. The 3' end of the gene was determined by sequencing cDNA from cerebrum mRNA.

The coding sequence of sheep SPRN has 93\% respectively $78 \%$ nucleic acid identity, and 95\% respectively $76 \%$ amino acid identity with cow and man. The complete sequence obtained here (Genbank:DQ870545) has 92\% nucleic acid identity with the bovine SPRN sequence (Genbank:DQ058606). The GC content of the coding sequence in sheep is high (79\%), as in cow (77\%) and man $(79 \%)$. The overall GC content of the obtained SPRN sequence in sheep is $70 \%$.

Comparison of the deduced amino acid sequence between sheep and other mammals reveals a high level of conservation in the typical hydrophobic region of SPRN (see Figure 3). This hydrophobic sequence, containing the palindrome sequence AGAAAGA, is a typical characteristic of SPRN and is very similar to the hydrophobic region found in PrP and PrP-like proteins $[23,28,29]$. In prion protein, this region has remained highly conserved during evolution $[27,33]$ and thus may be an important functional region. The synthetic peptide PrP 106-126, containing the hydrophobic sequence, has been shown neurotoxic in vitro and in vivo $[34,35]$ and this neurotoxicity seems to depend on the presence of the palindrome sequence [36]. The hydrophobic region also plays a role in the conversion of $\mathrm{PrPC}^{\mathrm{C}}$ into PrPsc. $\mathrm{PrPC}^{\mathrm{C}}$ without the palindrome sequence can not be converted into $\mathrm{PrPSc}^{\mathrm{Sc}}$ [3] and does not bind with $\mathrm{PrPSC}^{\mathrm{Sc}}$ or PrP 106-126 [38]. Moreover, a PrP transgene expressing a mutant PrP with a deletion of the palindrome region acts as a dominant-negative mutant, inhibiting the conversion of wild-type $\mathrm{PrPC}^{\mathrm{C}}$ into PrPSc [38].

\section{Transcription profiling of SPRN by RT-PCR}

After isolation of total RNA and subsequent conversion to CDNA, the presence of SPRN transcripts was examined by RT-PCR with SPRN primer no. 9 in 21 different tissues. The RT-PCR, performed in triplicate, showed high levels of SPRN mRNA in cerebrum and cerebellum (Figure 4a) and low levels in testis, lymph node, jejunum, ileum, colon and rectum (very faint bands on Figure 4a). No SPRN mRNA was detected in obex, spleen, kidney, liver, lung, heart, muscle, tongue, rumen, omasum, abomasum, duodenum and caecum. An RT-PCR with SPRN primer no. 11 , also performed in triplicate, on the same tissues showed similar patterns. The results of a control PCR with ACTB primers are shown in Figure $4 \mathrm{~b}$.

These results of the transcription profiling in sheep are in good agreement with the data available in other species. Results of RT-PCR and Northern blot analyses in cattle [24], RT-PCR in rat [23] and cDNA, EST and SAGE map data analyses in man and mouse [25] all show that expression of SPRN is highest in brain tissue. Comparison of the $S P R N$ transcription profile of the non-brain tissues between sheep and other species is more difficult, as the transcription level is lower in the other positive tissues, in sheep as well as in cow and rat.

Transcription profiling was performed by RT-PCR. This method permits the rapid testing of a large number of different tissues for the presence of a certain transcript. RTPCR does not give detailed quantitative information on expression, therefore more time consuming methods like 
Table 3: Amplicon characteristics of the SPRN primers used.

\begin{tabular}{|c|c|c|c|}
\hline $\begin{array}{c}\text { Number SPRN } \\
\text { primers }\end{array}$ & $\begin{array}{l}\text { Forward primer }\left(5^{\prime}-3^{\prime}\right) \\
\text { Reverse primer (5'-3') }\end{array}$ & $\begin{array}{c}\mathrm{Ta}\left({ }^{\circ} \mathrm{C}\right) \\
\text { Length (bp) }\end{array}$ & $\begin{array}{l}\text { Position in sequence } \\
\text { DQ870545 }\end{array}$ \\
\hline I & $\begin{array}{c}\text { ACTCCGGCTCTGGGCTCTGT } \\
\text { GGCTCTGTCTTGCTTTCCAAGGT }\end{array}$ & $\begin{array}{l}63 \\
645\end{array}$ & I-645 \\
\hline 2 & $\begin{array}{l}\text { TTCAGGGACCACAGGATCGAA } \\
\text { CCACGGGCTTCAGCACCTC }\end{array}$ & $\begin{array}{l}60 \\
487\end{array}$ & 549-1035 \\
\hline 3 & $\begin{array}{l}\text { GTGCGAAGTTGGGGTGAGGA } \\
\text { AGCGGGTGAGGGTCTGGAAG }\end{array}$ & $\begin{array}{c}60 \\
330\end{array}$ & $973-1302$ \\
\hline 4 & $\begin{array}{l}\text { GAGGACGGATGCGGTGGAG } \\
\text { CCAAAGGAAGCGGGTGAGG }\end{array}$ & $\begin{array}{l}64 \\
601\end{array}$ & $988-1588$ \\
\hline 5 & $\begin{array}{l}\text { CAGGGGTCGCCTCTGGTC } \\
\text { CTGCTGGAGGAGTGGGGAGT }\end{array}$ & $\begin{array}{c}64 \\
507\end{array}$ & |375-|88| \\
\hline 6 & $\begin{array}{l}\text { ACCCTCACCCGCTTCCTTTG } \\
\text { TAGCAGCAGAGCCCAGCACA }\end{array}$ & $\begin{array}{l}66 \\
486\end{array}$ & $1619-2104$ \\
\hline 7 & $\begin{array}{l}\text { CCGCCCCTGAGCCCTGAC } \\
\text { CCGCATCCTCCAGGCCAAG }\end{array}$ & $\begin{array}{c}66 \\
334\end{array}$ & $1967-2300$ \\
\hline 8 & $\begin{array}{l}\text { CCGTGTGCTGGGCTCTGCTG } \\
\text { GGCGCTCCGTCCTCTGCATC }\end{array}$ & $\begin{array}{c}68 \\
256\end{array}$ & $2082-2337$ \\
\hline 9 & $\begin{array}{l}\text { GCGAGGGTGCGTGTGAGG } \\
\text { CCTGAGGTCCACGCCCAGTA }\end{array}$ & $\begin{array}{c}68 \\
236\end{array}$ & $2189-2424$ \\
\hline 10 & $\begin{array}{l}\text { AGCTTGGCCCGGAGGATG } \\
\text { CCTGGGTGAGGGTGTTCTGG }\end{array}$ & $\begin{array}{l}66 \\
678\end{array}$ & 2384-306I \\
\hline 11 & $\begin{array}{l}\text { AGCCCACCCTGGACACTTGA } \\
\text { AGCTGGAGGGAAAAGCACCTG }\end{array}$ & $\begin{array}{l}66 \\
446\end{array}$ & $2852-3297$ \\
\hline 12 & $\begin{array}{l}\text { GGTGCGTCTGTGGATCTGTGAG } \\
\text { CTCCCGCTGGTCTTGTGGAG }\end{array}$ & $\begin{array}{l}66 \\
655\end{array}$ & $307 I-3725$ \\
\hline 13 & $\begin{array}{l}\text { TCTGGTTGCGGTCAGGGTCT } \\
\text { TGAAGTCGGGTTGTTGAGTGGAA }\end{array}$ & $\begin{array}{l}65 \\
423\end{array}$ & $3574-3996$ \\
\hline 14 & $\begin{array}{l}\text { GCCAGATGCCCTCCATCCTC } \\
\text { CTGCGAGCACCTTCCAGCTAA }\end{array}$ & $\begin{array}{l}65 \\
571\end{array}$ & $3760-4330$ \\
\hline 15 & $\begin{array}{c}\text { GGAGGGTCGCAACACCACT } \\
\text { GGCAGCAGAGTTTATTTCACCAC }\end{array}$ & $\begin{array}{c}65 \\
279\end{array}$ & $4226-4504$ \\
\hline 16 & $\begin{array}{l}\text { CCCGCTTCCAGAATGTGCAG } \\
\text { TCCCAGTTCCGTCATGGTCGT }\end{array}$ & $\begin{array}{c}66 \\
300\end{array}$ & $4263-4544$ \\
\hline 17 & $\begin{array}{l}\text { GTGACCTTCCTGCCCTTCAGGTGT } \\
\text { GTGTCTGCCCTTCAGCTTCGTGA }\end{array}$ & $\begin{array}{c}68 \\
250\end{array}$ & $4354-4544$ \\
\hline 18 & TCCCAGTTCCGTCATGGTCGTGTCTGCCCTTCAGCTTCGTGA(T) ${ }_{18}$ & - & - \\
\hline
\end{tabular}

real-time PCR or real competitive PCR are needed [39]. However, RT-PCR results give an overall view and can be the basis to choose tissues of interest for more extended, quantitative experiments.

\section{Conclusion}

In this study, SPRN as well as six genes surrounding the SPRN locus, ECHS1,PAOX,MTG1,LOC619207,CYP2E1 and SYCE1, have been identified in sheep for the first time. A contig containing these genes was constructed and annotated, suggesting conserved linkage between sheep and man in this region. The contig was FISH mapped to Oari22q24. A 4,544 bp fragment was also sequenced, covering the entire SPRN gene and 1206 bp of the promoter region. A high level of sequence homology was found with the bovine SPRN and, to a lesser extent, with the human SPRN. In addition, the transcription profile of SPRN was determined in 21 ovine tissues, confirming that $S P R N$ is mainly expressed in brain tissue. These results are the first description of the SPRN gene in sheep and should be useful as a basis for further research on this prion-like protein.

\section{Methods}

Primer design and PCR

Primers were designed with Primer3 [40] based on sequences found in NCBI Entrez Gene [41] or on BESs, and all amplicons were verified by sequencing. A list of the primers used with their conditions is given in Tables 2 and 3. PCR was performed with $0.5 \mathrm{U}$ Faststart Taq DNA Polymerase (Roche), $2.0 \mathrm{mM} \mathrm{Mg}$ and $200 \mu \mathrm{M}$ (each) dNTPs (Bioline) on 200 ng BAC DNA, 20-200 ng RNA or on reverse transcribed RNA. For the amplification of SPRN sequences, a 5x solution of GC-rich (supplied with the Faststart Taq DNA Polymerase) was added. PCR conditions were $5 \mathrm{~min}$ at $95^{\circ} \mathrm{C}, 40$ cycles of $30 \mathrm{~s}$ at $95^{\circ} \mathrm{C}, 30$ $\mathrm{s}$ at the annealing temperature and $1 \mathrm{~min}$ at $72^{\circ} \mathrm{C}$, and a final 10 min elongation at $72^{\circ} \mathrm{C}$. 


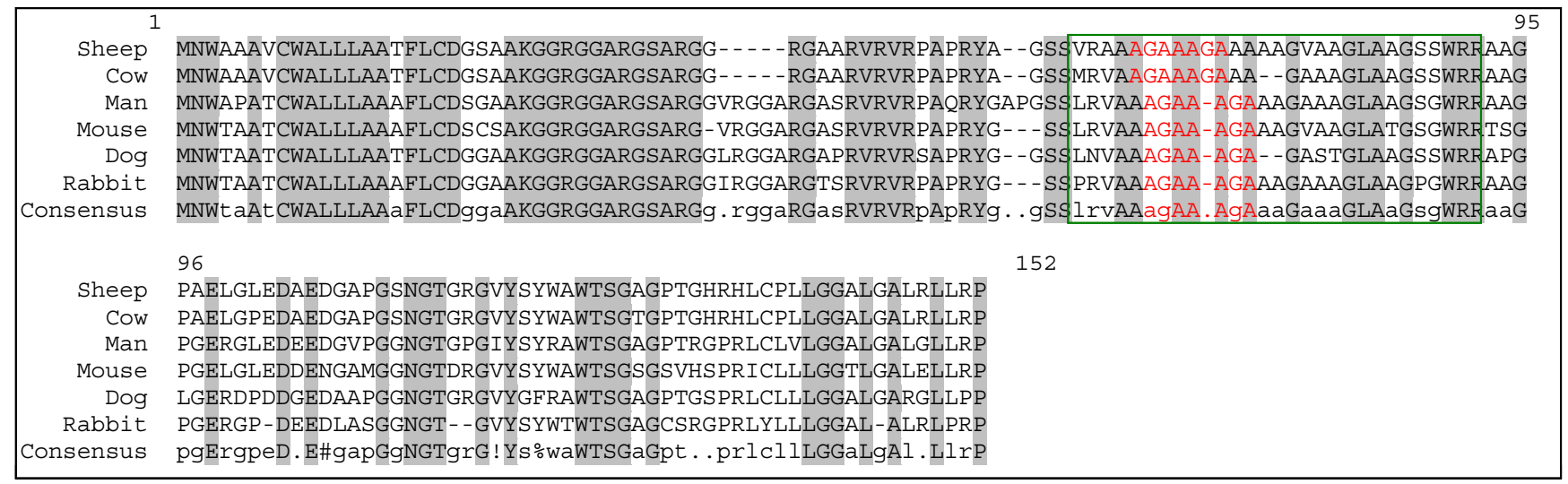

Figure 3

Comparison of the SPRN amino acid sequence in sheep and other mammals. The sequences used are sheep: Genbank:DQ870545, cow: Genbank:DQ058606, man: Genbank:NM 001012508, mouse: Genbank:NM 183|47, dog: Genbank:BN000838 and rabbit: Genbank:BN000843. Grey indicates conservation between the six species. The hydrophobic region is indicated with a green rectangle, the palindrome sequence is indicated in red.

\section{Construction and annotation of a BAC contig}

Primers for the genes PAOX and CYP2E1 were used for the initial screening of the INRA ovine BAC library by PCR [42]. BAC DNA from three isolated BAC clones was purified from $200 \mathrm{ml}$ culture using the Qiagen Plasmid Midi kit (Qiagen) and the BAC ends were sequenced with UP and RP, using $1 \mu \mathrm{g}$ DNA per reaction. Primers designed on the BESs of the isolated BAC clones were used to find overlaps between these BAC clones and the OariBAC273H7 UP primers were used to screen the INRA ovine BAC library for new BAC clones in order to close the gap between the two subcontigs. Annotation of the contig was performed by comparing BESs with the human genome sequence and by PCR with primers for genes presumed to be present in the contig. Comparisons were done with NCBI Blast [43] and repeat sequences were detected and identified with Repeatmasker Web Server [44].

\section{FISH}

For probe preparation, BAC DNA extracts were prepared according to standard protocols and purified with the S.N.A.P. K1900-01 Miniprep kit (Invitrogen life technologies). DNA was then labelled by nick-translation with biotin-14-dATP (BioNick 18247-015 labelling system, Invitrogen life technologies), mixed with 100x total sonicated herring sperm DNA and 100x total sonicated sheep DNA, ethanol precipitated, slightly dried and resuspended in hybridization buffer.

R-banded chromosome spreads were obtained from sheep embryo fibroblast cell cultures synchronized with an excess of thymidine and treated with 5-bromodeoxyuridine during the second half of S phase [45]. Fluorescent in situ hybridization, signal detection and R-banding were performed as previously described [46] with 50-100 ng of biotin-14-dATP labelled probe per slide. Before hybridization to the chromosomes, probes were denatured at $100^{\circ} \mathrm{C}$ for $10 \mathrm{~min}$ and pre-hybridized at $37^{\circ} \mathrm{C}$ for $30-60$ min. Slides were examined under a Zeiss Axioplan 2 epifluorescence microscope and the Applied Imaging Cytovision (version 2.7) software was used for image capturing and analysis. Chromosome identification and band nomenclature for sheep chromosomes follow the Rbanded standard ideogram reported in ISCNDB2000 [47].

\section{Sequencing}

For sequencing SPRN in sheep, the primers mentioned in Table 3 were used. Amplicons of the SPRN primers no. 2, 3, 4 and 5 were cloned and sequenced with UP and RP. The other amplicons were sequenced by direct sequencing.

The 3' end of the ovine SPRN sequence was obtained using mRNA from cerebrum tissue, isolated with the Illus$\operatorname{tra}^{\mathrm{TM}}$ Quickprep Micro mRNA Purification kit according to the manufacturer's protocol. The obtained mRNA then was converted into cDNA with the Improm-II Reverse Transcriptase kit (Promega) using a newly designed oligo dT primer (SPRN primer no. 18) which adds 42 bp to the cDNA. Finally, a PCR with SPRN primers no. 16, followed by a PCR with the nested SPRN primers no. 17 (both cre- 
(a)

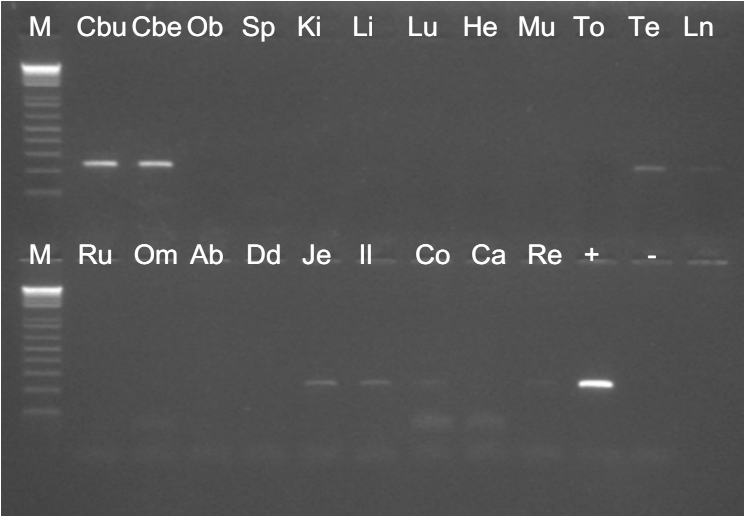

(b)

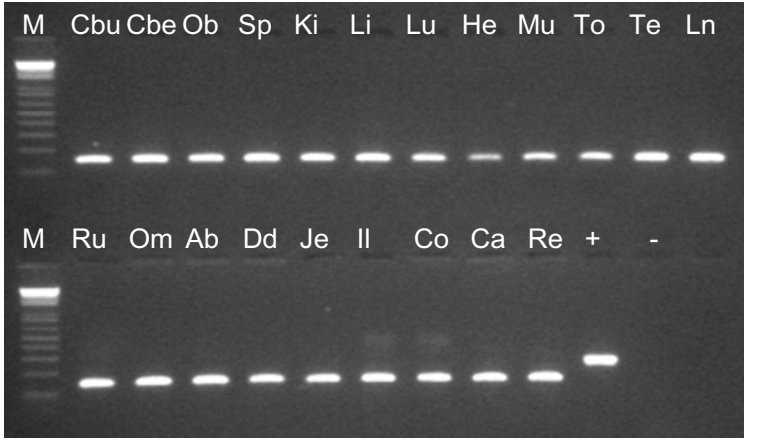

\section{Figure 4}

Transcription profiling of SPRN in $2 I$ sheep tissues. (a) RT-PCR with SPRN primers no. 9 and (b) Control PCR with ACTB primers. Marker $(M)$ is the I $\mathrm{Kb}+$ ladder (Invitrogen). Samples are cDNA of cerebrum (Cbu), cerebellum (Cbe), obex (Ob), spleen (Sp), kidney (Ki), liver ( $(\mathrm{Li})$, lung $(\mathrm{Lu})$, heart $(\mathrm{He})$, muscle (Mu), tongue (To), testis (Te), lymph node ( $\mathrm{Ln})$, rumen $(\mathrm{Ru})$, omasum $(\mathrm{Om})$, abomasum $(\mathrm{Ab})$, duodenum (Dd), jejunum (Je), ileum (II), colon (Co), caecum (Ca), rectum $(\mathrm{Re})$, positive control $(+)$ and negative control $(-)$.

ating an amplicon including the polyA sequence) was performed on 10x diluted cDNA and the obtained amplicon was directly sequenced with SPRN primers no. 17.

All sequencing was performed on a Applied Biosystems 3730xl DNA Analyser with the BigDye Terminator v3.1 Cycle Sequencing Kit (Applied Biosystems).

\section{RNA isolation, CDNA synthesis and RT-PCR}

Tissues for RNA isolation were collected in a commercial sheep slaughterhouse, immediately frozen in liquid nitrogen, crushed to powder the same day and stored at $-80^{\circ} \mathrm{C}$. Total RNA was isolated with the Rneasy plus mini kit (Qiagen) on $30 \mathrm{mg}$ tissue, except for heart, muscle and tongue, where TRIR (ABgene) and 80-100 mg tissue were used. Both methods were performed according to the manufacturer's protocol and followed by a DNase treatment with RQ1 RNase-free DNase (Promega) and a spin- column purification with Microcon YM-100 (Millipore), according to the product's user guides. RNA concentration and $\mathrm{OD}_{260 / 280}$ ratio of the samples were measured with the Nanodrop ND-1000 Spectrophotometer (Isogen) and RNA quality was measured by evaluation of the $28 \mathrm{~S}$ and the $18 \mathrm{~S}$ ribosomal bands on a $0.8 \%$ agarose gel. Also, a minus RT-PCR was performed on $1 \mu \mathrm{l}$ RA to confirm the absence of any DNA contamination. After RNA controls, 0.2-1 $\mu \mathrm{g}$ RNA was converted into cDNA with the Improm-II Reverse Transcriptase kit (Promega) using Random and Oligo dT primers (each $0.5 \mu$ g per reaction), and the conversion was confirmed by a PCR with ACTB primers (giving an amplicon of different length on gDNA and cDNA) on 10x diluted cDNA. Determination of the transcription profile of SPRN was performed with SPRN primers no. 9 and $S P R N$ primers no. 11 on 10x diluted cDNA.

\section{List of abbreviations}

ACTB: gene coding for actin-beta

ARR: genotype of PRNP coding for alanine-argininearginine at positions 136, 154 and 171 of $\operatorname{PrP}$

BAC: bacterial artificial chromosome

BES: BAC end sequence

BSE: bovine spongiform encephalopathy

Btau: Bos taurus

cDNA: complementary DNA

CYP2E1: gene coding for cytochrome P450, family 2, subfamily E, polypeptide 1

ECHS1: gene coding for enoyl Coenzyme A hydratase, short chain, 1, mitochondrial

ERV: endogenous retrovirus

EST: expressed sequence tag

FISH: fluorescence in situ hybridization

gDNA: genomic DNA

HTG: high throughput genomic sequence

Hsap: Homo sapiens

LINE: long interspersed nuclear element

LOC619207: gene coding for scavenger receptor protein family member 


\section{LTR: long terminal repeat}

MTG1: gene coding for mitochondrial GTPase 1 homolog (S. cerevisiae)

Oari: Ovis aries

PAOX: gene coding for polyamine oxidase (exo-N4amino)

PCR: polymerase chain reaction

PRND: gene coding for prion protein 2 (dublet)

PRNP: gene coding for prion protein

PrP: prion protein

PrPC: cellular form of the prion protein

PrPSc: disease causing form of the prion protein

RP: reverse primer

RT: reverse transcriptase

SAGE: serial analysis of gene expression

SPRN: gene coding for Shadow of prion protein

SYCE1: gene coding for synaptonemal complex central element protein 1

TSE: transmissible spongiform encephalopathy

UP: universal primer

\section{Authors' contributions}

EL carried out the contig building and annotation, the sequencing, the transcription profiling, and drafted this manuscript. MVP participated in the study design and provided experimental support. $\mathrm{KH}$ performed the BAC screening. HH supervised the FISH mapping. AVZ supervised the study. LJP participated in the study design and also supervised the study. All authors read and approved the final manuscript.

\section{Acknowledgements}

The authors wish to thank Dominique Vander Donckt, Céline DucroixCrépy, Maud Bertaud and Elien Imant for excellent technical assistance. Evelyne Lampo is Research Assistant of the Research Foundation-Flanders (FWO).

\section{References}

I. Prusiner SB: Prions. Proc Natl Acad Sci USA 1998, 95:|3363-13383.

2. Dalsgaard NJ: Prion diseases. An overview. APMIS 2002, I I 0:3-I 3.
3. Fasano C, Campana V, Zurzolo C: Prions: protein only or something more? Overview of potential prion cofactors. J Mol Neurosci 2006, 29:|95-2|4.

4. Kaneko K, Zulianello L, Scott M, Cooper CM, Wallace AC, James TL, Cohen FE, Prusiner SB: Evidence for protein $\mathbf{X}$ binding to a discontinuous epitope on the cellular prion protein during scrapie prion propagation. Proc Natl Acad Sci USA 1997, 94:10069-10074.

5. Hunter N: Scrapie and experimental BSE in sheep. Br Med Bull 2003, 66:171-183.

6. Buschmann A, Luhken G, Schultz J, Erhardt G, Groschup MH: Neuronal accumulation of abnormal prion protein in sheep carrying a scrapie-resistant genotype (PrPARR/ARR). J Gen Virol 2004, 85:2727-2733.

7. Madec JY, Simon S, Lezmi S, Bencsik A, Grassi J, Baron T: Abnormal prion protein in genetically resistant sheep from a scrapieinfected flock. J Gen Virol 2004, 85:3483-3486.

8. Orge L, Galo A, Machado C, Lima C, Ochoa C, Silva J, Ramos M, Simas JP: Identification of putative atypical scrapie in sheep in Portugal. J Gen Virol 2004, 85:3487-349l.

9. De Bosschere H, Roels S, Dechamps P, Vanopdenbosch E: TSE detected in a Belgian ARR-homozygous sheep via active surveillance. Vet J 2007, I 73:449-45I.

10. Le Dur A, Beringue V, Andréoletti O, Reine F, Lai TL, Baron T, Bratberg B, Vilotte JL, Sarradin P, Benestad SL, Laude H: A newly identified type of scrapie agent can naturally infect sheep with resistant PrP genotypes. Proc Natl Acad Sci USA 2005, 102:1603|-16036.

II. Saunders GC, Cawthraw S, Mountjoy SJ, Hope J, Windl O: PrP genotypes of atypical scrapie cases in Great Britain. J Gen Virol 2006, 87:3|4|-3|49.

12. Houston F, Goldmann W, Chong A, Jeffrey M, Gonzalez L, Foster J, Parnham D, Hunter N: Prion diseases: BSE in sheep bred for resistance to infection. Nature 2003, 423:498.

13. Andréoletti O, Morel N, Lacroux C, Rouillon V, Barc C, Tabouret G, Sarradin P, Berthon P, Bernardet P, Mathey J, Lugan S, Costes P, Corbiere F, Espinosa JC, Torres JM, Grassi J, Schelcher F, Lantier F: Bovine spongiform encephalopathy agent in spleen from an ARR/ARR orally exposed sheep. J Gen Virol 2006, 87: I043-I046.

14. Hill AF, Collinge J: Subclinical prion infection in humans and animals. Br Med Bull 2003, 66: 161-170.

15. Thackray AM, Klein MA, Bujdoso R: Subclinical prion disease induced by oral inoculation. J Virol 2003, 77:799|-7998.

16. Golinska E, Flirski M, Liberski PP: Doppel: the prion's double. Folia Neuropathol 2004, 42(Suppl A):47-54.

17. Qin K, O'Donnell M, Zhao RY: Doppel: more rival than double to prion. Neuroscience 2006, I4I:I-8.

18. Hundt C, Peyrin JM, Haik S, Gauczynski S, Leucht C, Rieger R, Riley $\mathrm{ML}$, Deslys JP, Dormont D, Lasmezas CI, Weiss S: Identification of interaction domains of the prion protein with its $37-\mathrm{kDa} / 67$ kDa laminin receptor. EMBO J 200 I, 20:5876-5886.

19. Petrakis S, Sklaviadis T: Identification of proteins with high affinity for refolded and native PrP(C). Proteomics 2006, 6:6476-6484.

20. Xiang W, Wind O, Wunsch G, Dugas M, Kohlmann A, Dierkes N, Westner IM, Kretschmar HA: Identification of differentially expressed genes in scrapie-infected mouse brains by using global gene expression technology. J Virol 2004, 78: I I 05 I- I I 060.

21. Brown AR, Rebus S, McKimmie CS, Robertson K, Williams A, Fazakerley JK: Gene expression profiling of the preclinical scrapieinfected hippocampus. Biochem Biophys Res Commun 2005, 334(I):86-95.

22. Skinner PJ, Abbassi H, Chesebro B, Race RE, Reilly C, Haase AT: Gene expression alterations in brains of mice infected with three strains of scrapie. BMC Genomics 2006, 7: I |4.

23. Premzl M, Sangiorgio L, Strumbo B, Marshall Graves JA, Simonic T, Gready JE: Shadoo, a new protein highly conserved from fish to mammals and with similarity to prion protein. Gene 2003, 3। 4:89-102.

24. Uboldi C, Paulis M, Guidi E, Bertoni A, Meo GP, Perucatti A, lannuzzi L, Raimondi E, Brunner RM, Eggen A, Ferretti L: Cloning of the bovine prion-like Shadoo (SPRN) gene by comparative analysis of the predicted genomic locus. Mamm Genome 2006, I 7: I130-1139.

25. Premzl M, Gamulin V: Comparative genomic analysis of prion genes. BMC Genomics 2007, 8: I.

26. Premzl M, Gready JE, Jermiin LS, Simonic T, Marshall Graves JA: Evolution of vertebrate genes related to prion and Shadoo proteins-clues from comparative genomic analysis. Mol Biol Evol 2004, $21: 2210-2231$.

27. Lee IY, Westaway D, Smit AF, Wang K, Seto J, Chen L, Acharya C, Ankener M, Baskin D, Cooper C, Yao H, Prusiner SB, Hood LE: Complete genomic sequence and analysis of the prion protein 
gene region from three mammalian species. Genome Res 1998 , 8: $1022-1037$

28. Oidtmann B, Simon D, Holtkamp N, Hoffmann R, Baier M: Identification of cDNAs from Japanese pufferfish (Fugu rubripes) and Atlantic salmon (Salmo salar) coding for homologues to tetrapod prion proteins. FEBS Lett 2003, 538:96-100.

29. Suzuki T, Kurokawa T, Hashimoto H, Sugiyama M: cDNA sequence and tissue expression of Fugu rubripes prion protein-like: a candidate for the teleost orthologue of tetrapod PrPs. Biochem Biophys Res Commun 2002, 294:912-917.

30. Büeler H, Fischer M, Lang Y, Bluethmann H, Lipp H-P, DeArmond SJ, Prusiner SB, Aguet M, Weissmann C: Normal development and behaviour of mice lacking the neuronal cell-surface PrP protein. Nature 1992, 356:577-582.

3I. Richt JA, Kasinathan P, Hamir AN, Castilla J, Sathiyaseelan T, Vargas F, Sathiyaseelan J, Wu H, Matsushita H, Koster J, Kato S, Ishida I, Soto C, Robl JM, Kuroiwa Y: Production of cattle lacking prion protein. Nat Biotechnol 2007, 25: I32-138.

32. lannuzzi L, Di Meo GP, Perucatti A, Incarnato D: Comparison of the human with the sheep genome by use of human chromosome-specific painting probes. Mamm Genome 1999, 10:719-723.

33. Schatzl HM, Da Costa M, Taylor L, Cohen FE, Prusiner SB: Prion protein variation among primates. J Mol Biol I995, 245:362-374.

34. Bergström AL, Cordes $H$, Zsurger $N$, Heegaard PM, Laursen $H$, Chabry J: Amidation and structure relaxation abolish the neurotoxicity of the prion peptide PrPI06-126 in vivo and in vitro. I Biol Chem 2005, 280:231|4-23।21.

35. Fioriti L, Quaglio E, Massignan T, Colombo L, Stewart RS, Salmona M, Harris DA, Forloni G, Chiesa R: The neurotoxicity of prion protein (PrP) peptide 106-I 26 is independent of the expression level of PrP and is not mediated by abnormal PrP species. Mol Cell Neurosci 2005, 28:I65-I76.

36. Jobling MF, Stewart LR, White AR, McLean C, Friedhuber A, Maher F, Beyreuther K, Masters CL, Barrow CJ, Collins SJ, Cappai R: The hydrophobic core sequence modulates the neurotoxic and secondary structure properties of the prion peptide I06-I 26. J Neurochem 1999, 73:1557-1565.

37. Norstrom EM, Mastrianni JA: The AGAAAAGA palindrome in $\mathrm{PrP}$ is required to generate a productive $\mathrm{PrPSc}-\mathrm{PrPC}$ complex that leads to prion propagation. I Biol Chem 2005, 280:27236-27243.

38. Brown R: PrPSc-like prion protein peptide inhibits the function of cellular prion protein. Biochem ] 2000, 352:5II-5 I 8 .

39. Ding C, Cantor CR: Quantitative analysis of nucleic acids - the last few years of progress. J Biochem Mol Biol 2004, 37: I- I0.

40. Rozen S, Skaletsky HJ: Primer 3 on the WWW for general users and for biologist programmers. Bioinformatics Methods and Protocols: Methods in Molecular Biology 2000:365-386 [http:// frodo.wi.mit.edu/cgi-bin/primer3/primer3 www.cgi]. Totowa: Humana Press

4I. NCBI Entrez Gene [http://www.ncbi.nlm.nih.gov/gquery/ gquery.fcgi?otool=ibeuglib\&otool=ibeuglib]

42. Vaiman D, Billault A, Tabet-Aoul K, Schibler L, Vilette D, Oustry Vaiman A, Soravito C, Cribiu EP: Construction and characterization of a sheep BAC library of three genome equivalents. Mamm Genome 1999, 1 0:585-587.

43. Altschul SF, Gish W, Miller W, Myers EW, Lipman DJ: Basic loca alignment search tool. I Mol Biol 1990, 215:403-410 [http:// www.ncbi.nlm.nih.gov/BLAST/].

44. Repeatmasker Webserver (Institute for SystemsBiology) [http://www.repeatmasker.org/cgi-bin/WEBRepeatMasker]

45. Hayes H, Petit E, Dutrillaux B: Comparison of RBG-banded karyotypes of cattle, sheep, and goats. Cytogenet Cell Genet I991, 57:5I-55.

46. Hayes H, Petit E, Lemieux N, Dutrillaux B: Chromosomal localization of the ovine beta-casein gene by non-isotopic in situ hybridization and R-banding. Cytogenet Cell Genet 1992, 61:286-288.

47. Cribiu EP, Di Berardino D, Di Meo GP, Eggen A, Gallagher DS, Gustavsson I, Hayes H, lannuzzi L, Popescu CP, Rubes J, Schmutz S, Stranzinger G, Vaiman A, Womack J: International System for Chromosome Nomenclature of Domestic Bovids (ISCNBD 2000). Cytogenet Cell Genet 2001, 92:283-299.
Publish with Biomed Central and every scientist can read your work free of charge

"BioMed Central will be the most significant development for disseminating the results of biomedical research in our lifetime. "

Sir Paul Nurse, Cancer Research UK

Your research papers will be:

- available free of charge to the entire biomedical community

- peer reviewed and published immediately upon acceptance

- cited in PubMed and archived on PubMed Central

- yours - you keep the copyright

Submit your manuscript here:

http://www.biomedcentral.com/info/publishing_adv.asp
BioMedcentral 